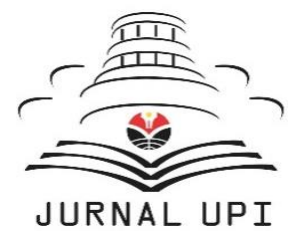

INDONESIAN JOURNAL OF APPLIED LINGUISTICS

Vol. 9 No. 3, January 2020, pp. 580-588

Available online at:

https://ejournal.upi.edu/index.php/IJAL/article/view/23208

doi: 10.17509/ijal.v9i3.23208

\title{
EFL teachers' perceived language proficiency and teaching effectiveness
}

\author{
Fazri Nur Yusuf* and Ophelia Elisa Novita \\ Department of English Education, Faculty of Language and Literature Education, Universitas Pendidikan Indonesia, \\ Jalan Dr. Setiabudhi No. 229 Bandung, West Java, Indonesia
}

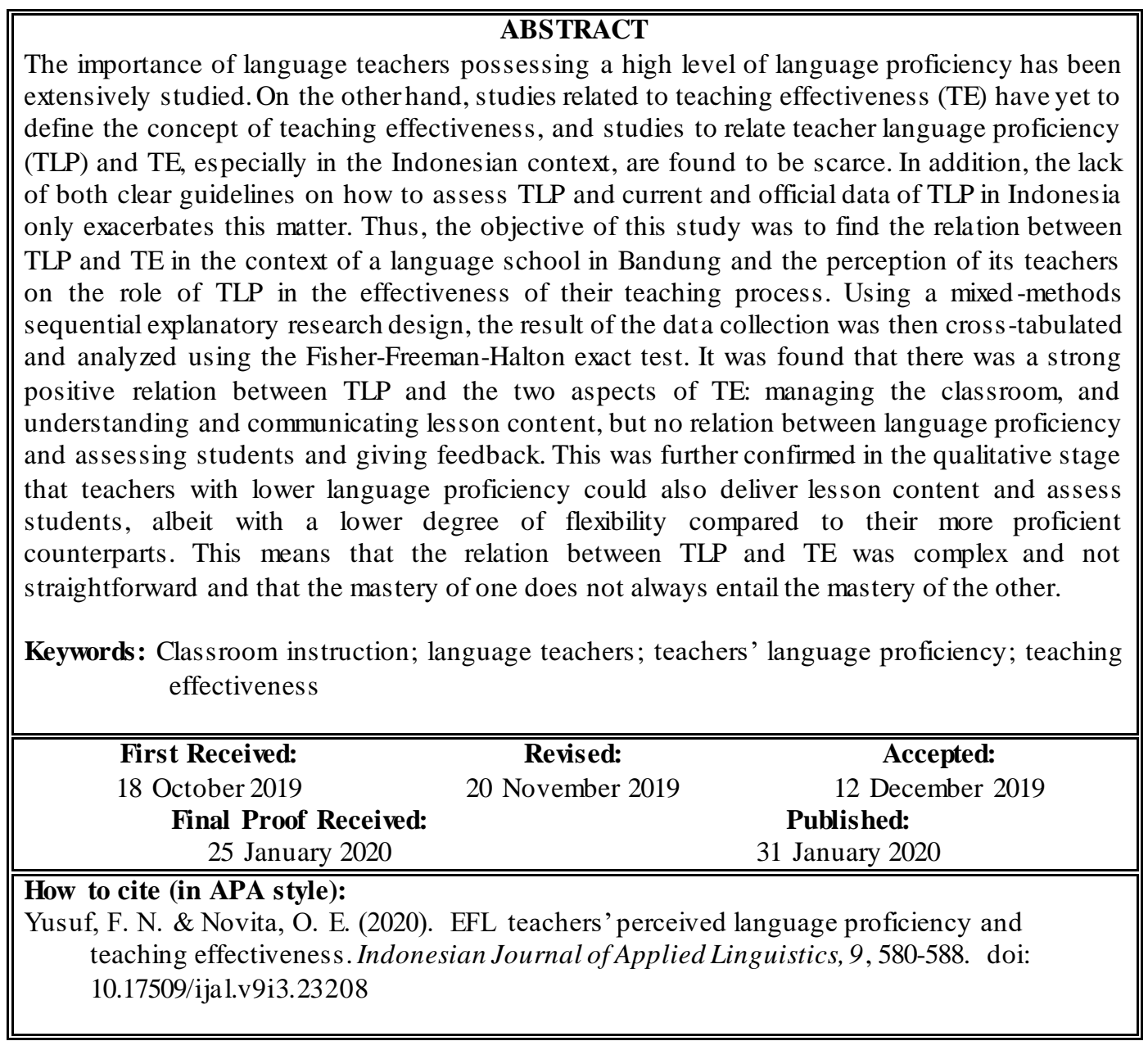

\section{INTRODUCTION}

With the continued rise of English to be used globally, whether because of globalization and emigration (Dewaele \& van Oudenhoven, 2009), the increase awareness of the importance of learning another language (Wallner, 2016), cross-cultural marriage (Logan-Terry, 2008; Qiu \& Winsler, 2017) , and an increase in the mobility of people around the world (Gathercole, 2010), there is an increased need in the provision of English teachers. However, a problem arises when this increase is not met by the availability of trained and proficient teachers. This can result in people with a lower degree of proficiency to be employed by schools or courses (Bailey, 2006).

The problem of English teachers having low language proficiency is also encountered in Indonesia. Unfortunately, there is no current nor official national data on EFL teachers' level of proficiency. Many local contexts studies found the prevalence of teachers with lower language proficiency level, stating that a large number of professional English teachers at formal schools are considered to have low competence to teach English to their students (Lie, 2007; Marcellino, 2008; Renandya, Hamied, \& Nurkamto, 2018; Soepriyatna, 2012).

\footnotetext{
* Corresponding Author

Email: fazrinuryusuf@upi.edu
} 
Although some countries in Asia such as Hong Kong, Japan, and Vietnam have implemented language proficiency tests and training (Nhung, 2017), however, there are no clear guidelines on what level of language proficiency a teacher needs to have to teach the English language at both formal and non-formal schools. Furthermore, there is no specific training to help teachers achieve a certain level of proficiency (Renandya, 2018).

On the other hand, while the importance of teacher language proficiency is commonly well recognized, the same cannot be conformed teaching effectiveness. Different from TLP, it is far more difficult to define TE as there are multiple facets of what constitutes effective teaching is, along with the fact that different researchers have different ideas on what teaching effectiveness is (Chambless, 2012). Thus, it is also not always easy to see the relations between how much TLP helps a teacher's TE.

The question arises, therefore, whether knowledge about the language system (also known as language awareness) automatically means higher language proficiency. A notion proposed by the famous second language acquisition theorist Stephen Krashen states that knowledge about language system does not contribute to language proficiency. In fact, at its worst, language awareness can impede one's language proficiency as the former was used only to monitor, not to initiate, sentences (Krashen, 1981). Although this notion has been criticized by some researchers on the theoretical ground (Donmall, 1985; McLaughlin, 1987), it shows that there should be a distinction between knowledge about the language and knowledge of the language. Thus, the assessment used to measure each should be made differently, as well.

In the end, TLP should not be treated equally to general English language proficiency (Freeman, Katz, Gomez, \& Burns , 2015). This is because TLP is a 'discourse competence' for the effective delivery of subject content (Elder, 2001) and 'specialized subset of language skills required to prepare and teach lessons' (Freeman et al., 2015). It means that the measurement of TLP should not only about the assessment of knowledge about the language but also the knowledge of the language.

Different from TLP, the multi-faceted concept of TE, combined with the lack of agreement from language teaching researchers about what constitutes effective teaching, makes it a difficult term to define (Chambless, 2012; Kern, 1995). One possible reason why it is hard to define the concept of TE is the ongoing debate whether to define TE as "teacher inputs (e.g., qualifications), the teaching process (e.g., instructional practices), the product of teaching (e.g., effects on student learning), or a composite of these elements." (Stronge, Ward, \& Grant , 2011, p. 340). One theoretical concept states that it is the level of how teachers can help facilitate their students' learning (Farrell, 2015), and another as the teachers' ability to stimulate creative and active teaching as well as the ability to instill the passion for learning for the future in students (Muijs, 2006).

However, although most literature does not define TE per se, they list important aspects of it, and together, the effectiveness of each of these aspects creates a description of effective teaching. These aspects can vary from one research to another; for instance, they are teachers' ability to adopt innovative techniques, commitment to teaching, classroom management, and ability to predict students' success (Ortaçtepe \& Akyel, 2015), reinforcement, cues and feedback, subject mastery (Fraser et al., 1987), feedback, cooperative learning, and adaptive instruction (Scheerens \& Bosker, 1997), and language proficiency (Lazaraton, 2004; Turnbull \& Arnett, 2002). Another research this study was anchored on called English-for-Teaching by Freeman, Katz, Gomez, and Burns in 2015, focuses on three aspects of TE: managing the classroom (TE 1), understanding and communicating lesson content (TE 2), and assessing students and giving feedback (TE 3). In this sense, a teacher's efficiency is measured by her ability in providing good language models, maintaining use of English in the classroom, giving explanations and instructions in English, providing examples of words and grammatical structures, giving accurate explanation of meaning of English words and grammatical items, using and adapting authentic English language resources in teaching, monitoring one's own speech and writing for accuracy, giving correct feedback on learner language use, providing input at an appropriate level of difficulty, and engaging in improvisational teaching (Richards, 2015).

Although it would be naïve to say that language proficiency is the only factor to determine a teacher's success, the level of which, or lack thereof, often plays a role in how well a teacher teaches (Freeman et al., 2015; Lie, 2007). It confirms that a high TLP in a language teacher can be helpful in determining students' success in learning a language because these teachers are able to give more accurate explanations and richer language input (Richards, Conway, Roskvist, \& Harvey, 2013), have higher flexibility in the use of the language and be more confident in delivering their lessons (Nhung, 2017) compared with their lower proficiency counterparts. TLP is also important in a way that teachers with higher TLP are reported to have higher confidence in delivering their lessons and that this attitude is passed on to their students, causing them to have a more positive attitude on the target language (Banno, 2003).

\section{METHODS}

This study focuses on EFL TLP and TE of English teachers in a language school in Bandung, Indonesia. The research problems are (1) whether there is a relationship between teachers' language proficiency and the effectiveness of their teaching process, and (2) how teachers perceive the role of language proficiency in the effectiveness of their teaching process to be. A mixed- 
methods sequential explanatory research design was employed. This study hypothesized that there was no relation between TLP and TE at the level of significance of .05.

Firstly, the data were collected by questionnaires and the academic team interviews. The three-part questionnaire was used to find three aspects of the study: teachers' results of the standardized tests they had taken (considered as externally assessed TLP), teacher's perception of their own TLP (considered as internally assessed TE), as well as their perception of their TE (considered as internally assessed TE). The second part of the study was academic team interviews. It is to find out teachers' TE based on the observations they had done to the teachers (considered as externally assessed TE). The data were then analyzed using a twodimensional chi-square. Chi-square was chosen because the data for both TLP and TE were in the form of frequency counts. The teachers participating in this study came from three branches of an English language course in Bandung, Indonesia. Forty-one participants were chosen because of the accessibility to conduct this research in this site and because the English language was used exclusively by the teachers' in-class sessions.

The levels of CEFR were used as the standardization of TLP in this study for two reasons. Firstly, CEFR provided a complete and comprehensive framework of the English language proficiency levels, and because CEFR described the language in terms of one's ability to use it by using a set of can make statements, it could reduce the variability of what was considered one level to another (Council of Europe, 2001). Secondly, with different tests taken by the teachers, using a CEFR leveling was a way to ensure a consistent result for all the teachers was achieved.

Furthermore, a comprehensive framework from the Australian professional standards for teachers was adapted because it provided a complete categorization of TE along with each category comprehensively (Australian professional standards for teachers, 2018). The categories focusing on the three aspects of teaching effectiveness in the study were used in four levels: Graduate, Proficient, Highly Accomplished, and Lead to sort teachers in their respective levels of TE, and the statements of each category were made into can do statement, following the format of CEFR.

The Fisher-Freeman-Halton exact test resulted in significant value, and this was compared to the null hypothesis formulated at the beginning of the study at the level of significance of .05 (Hatch \& Farhady,
1982). After finding whether there was a relation between TLP and TE, the strength of association value was calculated to find how strong the relation between these two variables was. Because the contingency table was bigger than $2 \times 2$, the strength of the association was seen from the Cramer's V value (Akoglu, 2018; Field, 2013), ranging from no or very weak relation to very strong.

In the second stage of the study, a qualitative phase was administered. Observations on how the teachers performed in the classroom and interviews with the two parties: teachers and the academic team became the main research instruments of collecting the data. From the 41 teachers partaking the first stage of the study, it can be seen that there were differences in the teachers' educational background. There was also a large range of teaching experience from more than 12 years to less than a year. Because of this significant differences in the teachers' general background, homogeneous purposive sampling was used in the second part of the study in terms of the level teachers were categorized, the branch that they taught so that the range of development programs they had experienced would be similar, and more importantly previous training in the target language. By choosing homogeneous purposive sampling, one could better concentrate on teachers with specific characteristics that could help her get a better understanding of the research questions (Etikan, 2016).

\section{FINDINGS}

The relation between TLP and TE

To understand the relation between TLP and TE, several different types of data were gathered: teachers' general background from the questionnaires and from the academic team interviews to better understand the condition happening in each school, TLP There were three aspects of TE gathered.

All of the data compiled and computed using the SPSS software to find the relation of TLP (from their own self-evaluation (considered internally assessed) and from the results of the standardized tests they had taken (considered externally assessed), and TE (TE1, managing the classroom; TE2; understanding and communicating lesson content; TE3, as sessing students and giving feedback) from teachers' self-evaluation (considered internally assessed) as well as the evaluation from the academic team (considered externally assessed).) and TE of all aspects show the overview and findings as follows (Table 1).

Table 1. Fisher-Freeman-Halton Exact Test result of TLP and TE

\begin{tabular}{llll}
\hline \multirow{2}{*}{ Fisher-Freeman-Halton exact test result } & \multicolumn{2}{l}{ Exact Sig (2-sided) } & \\
& TLP - TE $\mathbf{1}$ & TLP - TE 2 & TLP - TE 3 \\
\hline Internally assessed & 0.005 & 0.001 & 0.405 \\
Externally assessed & 0.022 & 0.008 & 0.119 \\
\hline
\end{tabular}

Table 1 indicates that the significance level between TLP and TE 1 and TLP and TE 2 was much lower than .05 , meaning that the result rejected the null hypothesis and that there was a relation between the two variables. However, the significance level between TLP and TE 3 was higher than .05 , meaning that the nulls hypothesis was accepted and that there was no relation between TLP and TE 3. 
To find out how strong the relations between TLP and TE 1 as well as TLP and TE 2, Cramer's V value was used to find the strength of association value, as seen in Table 2.

Table 2. Cramer's V value for TLP - TE 1 and TLP TE 2

\begin{tabular}{lcc}
\hline Cramer's V value & TLP - TE 1 & TLP - TE 2 \\
\hline Internally assessed & 0.384 & 0.446 \\
\hline Externally assessed & 0.349 & 0.444 \\
\hline
\end{tabular}

Table 2 shows that there is a very strong positive relationship between TLP and TE 1 for both internally and externally assessed TLP and TE 1 . A very strong and positive relationship was also found in the relation of TLP and TE 2 for both internally assessed TLP and TE 2. These results meant that with an increase in the TLP, there was a high possibility of an increase in the TE.

In addition, although not a focused objective of the study, it was also found that there was a strong positive relationship between teachers' perceived TLP and the TLP found from their standardized test, rejecting the null hypothesis at $72.3 \%$ level, with Cramer's V value of 0.226 (strong relation) meaning that most teachers could assess their own TLP accurately.

Teachers' perception of the role of TLP in the effectiveness of their teaching process

Five participants from the first stage of the study were chosen so that a more in-depth understanding about the relation between TLP and TE can be gathered, and from the data collected, reduced, displayed, and analyzed from the observations and in-depth interviews, some notable insights that related to and could strengthen the findings from the first stage of the study was found, in that a high TLP did not directly mean a high TE, and that teachers with lower language proficiency to an extent also possessed the ability to manage the classroom, understand and communicate lesson content, and assess students and give feedback although not with the same degree of flexibility compared to their more proficient colleagues.

In relation to whether TLP and TE were related, all the teachers asserted that there was a relationship between these two variables. They further explained that teachers with higher language proficiency could have better control of the language and better flexibility in adjusting their level of language. However, they also felt that language proficiency was only a factor and not the only factor in teaching effectiveness. Other factors that could help teachers achieve a good degree of TE, according to the teachers, were teachers' understanding of different learning styles, teachers' knowledge of various teaching methodologies and lesson content, communication skills, and his or her knowledge in psychology to understand different types of students.

In line with the findings from the quantitative stage of the study, teachers who were categorized as C1 and $\mathrm{C} 2$ showed more consistency in all aspects of TLP observed: speaking fluently, formulating questions clearly, and expressing ideas in different ways. However, teachers with lower TLP were also consistent in using correct spelling and punctuation in board work and handouts, and although at times they mispronounced some words, the ones they used as the model of target language were generally used accurately, and this is important as teachers should give an accurate model of language for the students (Richards et al., 2013).

In managing the classroom, teachers at all levels showed consistency in using English for grouping students, giving praise and encouragement, and controlling activities. This came from the fact that the use of English was made compulsory by the school in all stages of the lesson. In addition, as the school is a reputable English school in Bandung, the use of English in the classroom was not only made compulsory by the academic team of the school, but it was expected by the students or the parents of the students. Having this regulation and expectation can be an advantage for the teachers as they are more motivated to use English in their classroom, and it also compels the institutions to hire teachers with good language proficiency. However, it is also worth noting that it is easier for teachers to use English in all stages of the lesson in a language school where students in a class are divided - by means of diagnostic tests - based on their levels, thus sharing more or less the same level of language proficiency. In a formal school where students are more likely to be mixed-level, the challenge faced by the English teachers is to adjust their level of English to accommodate their students' different proficiency.

In understanding and communicating lesson content, all teachers consistently used English in presenting the target language. Similar to managing the classroom, this might arise from the fact that the use of English in all stages of the lesson was made compulsory by the school.

Teachers in higher levels showed more consistency in giving an accurate and meaningful explanation of the target language throughout the observations, although the presence of this could sometimes be lengthy. Another teacher in the higher level tended to dominate the students while presenting the target language, though this did not seem to bother the students.

However, the main problem encountered by teachers with lower language proficiency was that they tended not to adjust their level of English to match that of the students' in two ways. They either made the lesson too challenging for the students by using complicated words that were much higher than the students' level and most of the time these went unchecked, or they missed the opportunity to expand students' knowledge by introducing more subtle nuances of the languages, for example, the extreme meaning of despise and hate, or the level of formality of different phrases for requests.

Teachers' inability to adjust their level of English may arise from the fact that teachers with lower TLP 
have lower confidence in their English ability, and thus, they compensated this uncertainty by using more complex vocabulary. Another possibility is that their lexical resources are more limited than those of their higher proficiency peers', and thus, it is more challenging for them to maneuver the more subtle nuances of the language.

In assessing students and giving feedback, all teachers generally showed clear acceptance or rejection of students' responses, either by stating directly or implying this using hesitation or moving on to the next number. However, feedback on students' errors was sometimes overlooked by teachers of all levels. This might arise from the fact that some teachers did not monitor their students while doing their tasks, and some feedback given could be inappropriate in that teachers were focusing on the wrong aspects; for example, focusing on the accuracy of the students' speaking instead giving a feedback on the strategies used to keep the conversation going or ways to follow up somebody's statements. Another example is that teachers failed to give students a chance to self-correct, and by doing so, reduce their students' chance of becoming more autonomous.

\section{DISCUSSION}

The relation between TLP and TE

This study hypothesized that there was no relation between TLP and TE at 0.05 level of significance. From the data gathered, the significance value from the Fisher-Freeman-Halton exact test for the relation between TLP and TE 1 as well as TLP and TE 2 was sufficiently found significant to reject the null hypothesis. In conclusion, there was a relation between TLP and TE 1, and TLP and TE 2. Furthermore, from the computation of Cramer's V value to find the strength of this relation, it was found that TLP had a very strong relationship with both aspects of TE, with Cramer's V values of much higher than 0. 25 .

That TLP to an extent is important to help teachers teach better is not an unexpected finding, with studies confirming that good language proficiency is one of the factors in determining the success of the teachers' pedagogical practice (Andrews, 2003; Coniam \& Falvey, 1996; Faez \& Karas, 2017). However, it is also worth noting that these studies do not focus exclusively on the relation between TLP and TE and that they mention factors other than language proficiency as determining factors to teachers' effectiveness in teaching, for example, teaching ability and teachers' personality. To what extent TLP plays a role in determining TE is mostly left unexplored, and thus this study was focused on the targeted aspects of TE in the classroom.

An unanticipated result, conversely, was analyzed from the third aspect of TE, where it was found that the significance level of the relation between TLP and this aspect of TE was higher than 0.05 . This meant that the $\mathrm{H}_{0}$ was not rejected and that in turn meant that there was no relation between TLP and teachers' effectiveness in assessing their students and giving feedback.

These findings refute the idea that English teachers having high general language proficiency, oftentimes translated to NESTs, automatically possess the ability to teach effectively. While it is true that teachers who use English language consistently in the classroom can help make the language more authentic to the students and in turn support students clas sroomlanguage learning, these do not only happen in a classroom with a native speaker (Freeman, 2017), and that even teachers with a lower level of English proficiency can also provide, to an extent, appropriate target language models and corrective feedback (Richards et al., 2013). It is worth noting, however, that both the TLP and TE in this stage were taken from the unobserved results of teachers' standardized tests and the academic team evaluation. Thus, to validate this finding, a second stage was conducted where teachers were observed teaching.

In relation to TLP, although not a separate and focused part of the study, it was found that there was a strong positive relationship between teachers' perceived language proficiency with the results they attained from the standardized tests they had taken. The strong relation between these two variables might arise from the fact that teachers who have taken a form of standardized test and have seen the result of this test have a better general prediction of their language proficiency, which is in line with studies from Faez \& Karas, (2017) and Ross (1998), and even though this might not always be the case (Denies \& Janssen, 2016), when used together with other instruments, in this study's case teachers' classroom observations, it can give a noteworthy inside on how well teachers can assess their own language proficiency.

On the other hand, some studies stating that standardized tests are not the best means to measure TLP as it is a much more complex notion compared to general English proficiency (Butler, 2004; Renandya, 2018) and that even teachers with high IELTS scores do not always perform well in teachers training institutions (Elder, 1993). However, this fact further highlights the needs of a form of classroom language proficiency assessment for English language teachers in Indonesia so that a national and standardized leveling of TLP can be obtained to give a comprehensive understanding of TLP levels in Indonesia and in the long run a more targeted framework for teachers' professional development programs can be formulated.

\section{Teachers' perception of the role of TLP in the effectiveness of their teaching process}

All the participants confirmed that there was a relation between TLP and TE in those teachers with higher language proficiency could have better control of the language and could have better flexibility in adjusting their level of language to meet that of the students'. However, they felt that language proficiency was not the only factor of teaching effectiveness; rather, it was only one of the ways that could help teachers teach 
more effectively. Other factors that may come into play in helping teachers teach effectively, according to the participants, were teachers' understanding of different learning styles, teachers' personality, teachers' knowledge of various teaching methodologies and lesson content, communication skills, and their knowledge in psychology to understand different types of students. This statement was in line with what happened in the classroom during the observations, in that teachers with an approachable personality and better communication skills could help students become less self-conscious of their mistakes and be more open to suggestions compared to teachers who were slightly aloof and unapproachable despite their high TLP.

Teachers who also used different methods of teaching could build a better rapport with their students and enliven the teaching atmosphere, making it more enjoyable for students to interact with one another. This could be seen from the fact that teachers, regardless of their language proficiency, could interact communicatively with their students in the classroom.

The formulation of what helped teachers have a good degree of teaching effectiveness from these participants is in line with other studies affirming that there are many different aspects to help teachers teach effectively. These include teachers' detailed knowledge of the language (Coniam \& Falvey, 1996; Johnson, 2005; Pasternak \& Bailey, 2004). However, this content knowledge needs to be paired with teachers' pedagogical ability to deliver that detailed knowledge (Andrews, 2001), teachers' knowledge on culturallyappropriate ways of delivering the lesson and teacher's appropriate behavior (Pasternak \& Bailey, 2004), and the ability to use this content knowledge as the medium and target of instruction and at the same time the ability to adjust the level of language to meet students' level (Elder, 1994). This is in line with what happened in the classroom in that the ability to adjust the level of language to meet that of the students' was significant in helping students understand the target language taught, which was unsuccessfully done by teachers with lower TLP.

All participants but one also asserted that the school needed to provide some support to develop TLP, for example, in the form of workshops or thematic classes as these were seen as more continuous compared to workshops. The needs of schools or related institutions to provide support in their teachers' professional development, both for their language proficiency development as well as their teaching skills have been studied in many research (Cullen, 1994; Lengkanawati, 2005; Nakata, 2010; Renandya et al., 2018; Susilo, 2015), and from the interviews with the participants and the academic team, it was found that the schooldid provide teachers' development workshop. However, these were mainly directed to improving the teachers' instructional practices, for instance in how to teach grammar, how to teach exam preparation classes, how to teach mixed level classes, and how to mark students' writing. Classes or workshops to improve TLP had not been provided by the school with the consideration that teachers accepted to work in the place had already possessed a good level of TLP and that the responsibility of teachers to improve their TLP mostly fell on the teachers themselves. Additionally, the General Introduction to Teaching English (GITE) trainings teachers needed to take at the beginning of their work at school as well as the Cambridge certification teachers as encouraged to take did not really provide language improvement components in them. This situation is not uncommon to find in teacher development programs in general, where the focus is mostly on teaching methodology, taking TLP for granted (Cullen, 1994; Hobbs, 2013; Richards, 2017). However, when the academic team decided, through observations, that teachers needed to improve their TLP, or when teachers themselves felt that they need to become better in the language proficiency, the language school allowed these teachers to join existing higherlevel classes as a student free of charge. This practice is in line with the studies stating that the matter for professional development should be a shared responsibility between the institution and the individual teachers (Faez \& Valeo, 2012; Fraga-Canadas, 2010; Valmori, 2014; Yilmaz, 2011)

In addition, the findings from the observations and in-depth interviews with the participants gave an indepth insight in relation to the findings in the quantitative stage of the study in that a high language proficiency did not always mean a high teaching effectiveness, and that teachers with lower language proficiency also possessed the ability to manage the classroom, understand and communicate lesson content, and assess students and give feedback, albeit with a lower degree of flexibility compared to their more proficient counterparts.

From the observed lessons of the five teachers from different levels of proficiency, it was evident that in relation to TLP and TE, there were differences in the way teachers navigate their classroom. Teachers with higher language proficiency were not always consistent in all aspects of teaching effectiveness focused in this study. Similarly, teachers with lower language proficiency could also show some consistency in some aspects of TE. These teachers also had different views on what TLP and TE meant, and how TLP could help a teacher's teaching process.

\section{CONCLUSION}

From the first stage of the study, it was found that there is a strong positive relationship between teachers' perceived language proficiency and the results of the standardized tests they had taken. This means that most of the teachers could accurately assess their own proficiency as seen from the converted scores of these tests to the CEFR level. It was also found that that there was very a strong positive relation between TLP and TE 1 (managing the classroom) as well as TLP and TE 2 (understanding and communicating lesson content). On 
the other hand, the relation between TLP and the last TE indicator - assessing students and giving feedback was not found, which meant that there was no relation between these two aspects.

Most of the findings of the second stage of the study supported the findings on the first stage. Firstly, it was found that there was a relation between TLP and TE 2. Teachers with higher TLP were observed to give more accurate and meaningful target language explanations, and teachers with lower TLP did not consistently show their ability to adjust their level of English to meet the students' level. The finding related to TLP and TE 3 also supported the findings in the quantitative stage, in that there was no relation between TLP and TE 3. All teachers showed some difficulties in giving appropriate corrective feedback despite their levels. However, the strong relationship between TLP and TE 1 found in the first stage failed to be proven in the second stage of the study. Teachers of all levels of TLP showed similar difficulties in providing clear and concise instructions.

It can be concluded that the relation between TLP and TE is complex and not straightforward and that the mastery of one does not necessarily entail the mastery of the other. This can clearly be seen from the observed lessons that teachers with higher language proficiency also encountered some difficulties in some aspects of TE, similar to their lower-level counterparts. Similarly, teachers with lower proficiency also showed that they could be consistent in giving the target language explanation in English, in grouping learners, and in praising and encouraging their students. However, teachers with lower language proficiency were less consistent in adjusting their level of English to meet their students' level. They tended to use lexical resources, which were too challenging for their students, or they missed the chance to expand their students' knowledge by limiting the scope of the lesson to that which was too easy for them.

From this conclusion, there are two main implications of the study: theoretical and practical application, both for the school involved in the study specifically and at bigger scales generally. With a limited number of studies about the relation of TLP and TE, especially in a non-formal school context in Indonesia, this study can enrich the corpus on these topics. Additionally, because of the specific nature of this study, another implication comes from the practical application of the study, in that the framework used in this study can be adapted into a framework used by the school to observe and assess the teachers' effectiveness in their teaching process, especially in understanding and communicating lesson content, as this aspect was found to be strongly related to TLP in both stages of the study.

On a larger scale, the same framework can be used by the education policymakers in Indonesia and related educational stakeholders to create a more comprehensive framework of competence for EFL teachers and to create courses or workshops to help
Indonesian teachers become better English users and educators, and in turn, help improve Indonesian students' English language competence.

\section{REFERENCES}

Akoglu, H. (2018). User's guide to correlation coefficients. Turkish Journal of Emergency Medicine, 18(3), 91-93. doi: 10.1016/j.tjem.2018.08.001

Andrews, S. (2001). The language awareness of the L2 teacher: Its impact upon pedagogical practice. Language Awareness, 10(2), 75-90. doi: $10.1080 / 09658410108667027$

Andrews, S. (2003). Teacher language awareness and the professionalknowledge base of the L2 teacher. Language Awareness, 12(2), 81-95. doi: $10.1080 / 09658410308667068$

Australian professional standards for teachers. (2018). New South Wales: NSW Education Standards Authority.

Bailey, K. M. (2006). Language teacher supervision: A case-based approach. Cambridge: CUP.

Banno, E. (2003). A cross-cultural survey of students' expectations of foreign language teachers. Foreign Language Annals, 36(3), 339-346. doi: 10.1111/j.1944-9720.2003.tb02118.x

Butler, Y. G. (2004). What level of English proficiency do elementary school teachers need to attain to teach efl? Case studies from Korea, Taiwan, and Japan. TESOL Quarterly, 38(2), 245-278. doi: $10.2307 / 3588380$

Chambless, K. S. (2012). Teachers' oral proficiency in the target language: Research on its role in language teaching and learning. Foreign Language Annals, 45(1), 141-162. doi: 10.1111/j.19449720.2012.01183.x

Coniam, D., \& Falvey, P. (1996). Setting language benchmarks for English language teachers in Hong Kong secondary schools. Hong Kong: Advisory Committee on Teacher Education and Qualifications.

Council of Europe. (2001). Common European framework of reference for languages: Learning, teaching, assessment. Cambridge: Cambridge University Press.

$d q$ nCullen, R. (1994). Incorporating a language improvement component in teacher training programmes. ELT Journal,48(2), 162-172. doi; 10.1093/elt/48.2.162

Denies, K., \& Janssen, R. (2016). Country and gender differences in the functioning of CEFR-based cando statements as a tool for self-assessing English proficiency. Language Assessment Quarterly, 13(3), 251-276. doi: 10.1080/15434303.2016.1212055

Dewaele, J. M., \& van Oudenhoven, J. P. (2009). The effect of multilingualis $\mathrm{m} /$ multicu lturalis $\mathrm{m}$ on personality: No gain without pain for third culture kids? International Journal of Multilingualism, 
6(4), 443-459. doi: 10.1080/14790710903039906

Donmall, B. G. (1985). Language awareness: NCLE reports and papers 6 . London: Centre for Information and Language Teaching.

Elder, C. (1993). Language proficiency as predictor of performance in teacher education. Melbourne Papers in Language Testing, 2(1), 1-17.

Elder, C. (1994). Performance testing as benchmark for foreign language teacher education. Babel: Journal of the Australian Federation of Modern Language Teachers Associations, 29(2), 9-19.

Elder, C. (2001). Assessing the language proficiency of teachers: Are there any border controls? Language Testing, 18(2), 149-170. doi: 10.1177/026553220101800203

Etikan, I. (2016). Comparis on of convenience sampling and purposive sampling. American Journal of Theoretical and Applied Statistics, 5(1), 1-4. doi: 10.11648/j.ajtas.20160501.11

Faez, F., \& Karas, M. (2017). Connecting language proficiency to (self-reported) teaching ability: A review and analysis of research. RELC Journal, 48(1), 135-151. doi: 10.1177/0033688217694755

Faez, F., \& Valeo, A. (2012). TESOL teacher education: Novice teachers' perceptions of their preparedness and efficacy in the classroom. TESOL Quarterly, 46(3), 450-471. doi: 10.1002/tesq.37

Farrell, T. S. C. (2015). It's not who you are! It's how you teach! Critical competencies as sociated with effective teaching. RELC Journal,46(1), 79-88. doi: 10.1177/0033688214568096

Field, A. (2013). Discovering Statistics with IBM SPSS. Newbury Park: SAGE Publications.

Fraga-Canadas, C. P. (2010). Beyond the classroom: Maintaining and improving teachers' language proficiency. Foreign Language Annals, 43(3), 395-421. doi: 10.1111/j.1944-9720.2010.01090.x

Fraser, B. J., Walberg, H. J., Welch, W. W., \& Hattie, J. A. (1987). Syntheses of educational productivity research. International Journal of Educational Research, 11(2), 145-252. doi; 10.1016/08830355(87)90035-8

Freeman, D. (2017). The case for teachers' classroom English proficiency. RELC Journal, 48(1), 31-52. doi: 10.1177/0033688217691073

Freeman, D., Katz, A., Gomez, P. G., \& Burns, A. (2015). English-for-teaching: Rethinking teacher proficiency in the classroom. ELT Journal, 69(2), 129-139. doi: 10.1093/elt/ccu074

Gathercole, V. C. M. (2010). Bilingual children: Language and as sessment is sues for educators. In K. Littleton, C. Wood, \& J. K. Staarman (Eds.), International Handbook of Psychology in Education (1. ed). Bingley: Emerald.

$m$ Hatch, E., \& Farhady, H. (1982). Research design and statistics for applied linguistics. Rowley: Newbury House Publishers, Inc.

Hobbs, V. (2013). "A basic starterpack": The TESOL certificate as a course in survival. ELT Journal, 67(2), 163-174. doi: 10.1093/elt/ccs078
Johnson, K. (2005). Expertise in second language learning and teaching. Basingstoke: Palgrave McMillan.

Kern, R. (1995). Students and teachers' belief about language learning. Foreign Language Annals, 28(1), 71-92. doi: 10.1111/j.19449720.1995.tb00770

Krashen, S. (1981). Second language acquisition and second language learning. Oxford: Pergamon.

Lazaraton, A. (2004). Gesture and speech in the vocabulary explanations of one ESL teacher: A microanalytic inquiry. Language Learning, 54(1), 79-114. doi: 10.1111/j. 1467-9922.2004.00249.x

Lengkanawati, N. S. (2005). EFL Teachers' competence in the context of English curriculum 2004: Implications for EFL teacher education. TEFLIN Journal, 16(1), 79-92. doi: 10.15639/teflin journal.v16i1/79-92

Lie, A. (2007). Education policy and EFL curriculum in Indonesia: Between the commitment to competence and the quest for higher test scores. TEFLIN Journal,18(1), 1-14. doi: 10.15639/TEFLINJOURNAL. V18I 1/1-15

Logan-Terry, A. (2008). Raising children bilingually through the "One-parent-one-language" approach: A case study of Japanese mothers in the Australian context. Studies in Second Language Acquisition, 30(2), 267-268. doi: 10.1017/S027226310808042X

, 1-16doi: Marcellino, M. (2008). English language teaching in Indonesia: A continuous challenge in education and cultural diversity. TEFLIN, 19(1), 57-69. doi: 10.15639/teflin journal.v19i1/57-69

McLaughlin, B. (1987). Theories of second language learning. London: Arnold.

Muijs, D. (2006). New directions for school effectiveness research: Towards school effectiveness without schools. Journal of Educational Change, 7(3), 141-160. doi: 10.1007/s 10833-006-0002-7

Nakata, Y. (2010). Improving the clas sroom language proficiency of non-native teachers of English: What and how? RELC Journal, 41(1), 76-90. doi: $10.1177 / 0033688210362617$

Nhung, P. T. H. (2017). General English proficiency or English for teaching? The preferences of in-service teachers. RELC Journal, 49(3), 339-352. doi: $10.1177 / 0033688217691446$

Ortaçtepe, D., \& Akyel, A. S. (2015). The effects of a professional development program on english as a foreign language teachers' efficacy and classroom practice. TESOL Journal,6(4), 680-706. doi: 10.1002/tesj.185

Pasternak, M., \& Bailey, K. M. (2004). Preparing nonnative or nonnative speaker: Perceptions of nonnative speaking students in a graduate TESOL program. In L. D. Kamhi-Stein. (Ed.), Learning and teaching from experience: Perspective on nonnative english-speaking professionals. Ann Arbor, MI: University of Michigan Press. 
doi: Qiu, C., \& Winsler, A. (2017). Language use in a 'one parent-one language' Mandarin-English bilingual family: Noun versus verb use and language mixing compared to maternal perception. International Journal ofBilingual Education and Bilingualism, 20(3), 272-291. doi: 10.1080/13670050.2015.1044935

Renandya, W. (2018, February). What kind of English proficiency is needed for effective teaching? Paper presented at The Indonesian TESOL Summit, Jakarta.

Renandya, W., Hamied, F. A., \& Nurkamto, J. (2018). English language proficiency in Indonesia: Issues and prospects. The Journal of AsiaTEFL, 15(3), 618-629. doi: 10.18823/asiatef1.2018.15.3.4.618

Richards, H., Conway, C., Roskvist, A., \& Harvey, S. (2013). Foreign language teachers' language proficiency and their language teaching practice. The Language Learning Journal, 41 (2), 231-246. doi: 10.1080/09571736.2012.707676

Richards, J. C. (2015). Key issues in language teaching . Cambridge: Cambridge University Press.

Richards, J. C. (2017). Teaching English through English: proficiency, pedagogy and performance. RELC Journal,48(1), 7-30. doi: $10.1177 / 0033688217690059$

Ross, S. (1998). Self-as sessment in second language testing: A meta-analysis and analysis of experimental factors. Language Testing, 15(1), 120.

Scheerens, J., \& Bosker, R. J. (1997). The foundations of educational effectiveness. Oxford: Pergamon.

1- doi: 10.7275/tbfa-x148doi: Soepriyatna, S. (2012).
Investigating and asses sing competence of high school teachers of English in Indonesia. Malaysian Journal of ELT Research, 8(2), 38-49.

Stronge, J. H., Ward, T. J., \& Grant, L. W. (2011). What makes good teachers good? A cross-case analys is of the connection between teacher effectiveness and student achievement. Journal of Teacher Education, 62(4), 339-355. doi: $10.1177 / 0022487111404241$

Susilo, S. (2015). Curriculum of EFL Teacher Education and Indonesian Qualification Framework: A Blip of the Future Direction. Dinamika Ilmu, 15(1), 11-24. doi: 10.21093/di.v 15i1.98

Turnbull, M., \& Arnett, K. (2002). Teachers' use of target and first languages in second and foreign language classrooms. Annual Review of Applied Linguistics, 22(1), 204-218. doi: $10.1017 / \mathrm{S} 0267190502000119$

Valmori, L. (2014). How do foreign language teachers maintain their proficiency? MSU Working Papers in SLS, 5(1), 5-31. doi: 10.1016/j.sys tem.2016.02.003

Wallner, K. (2016). The effects of bilingualism on language development of children. Communication Sciences and Disorders: Student Scholarship \& Creative Works, 33(2), 137-141.

Yilmaz, C. (2011). Teachers' perceptions of selfefficacy, English proficiency, and instructional strategies. Social Behavior and Personality: An International Journal, 39(1), 91-100. doi: 10.2224/sbp.2011.39.1.91 